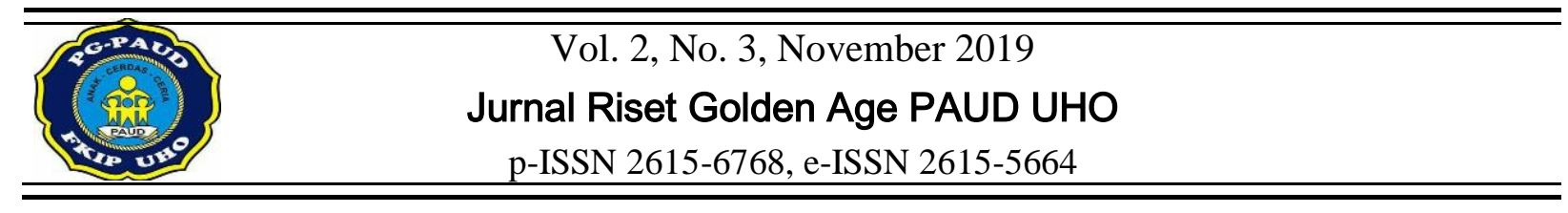

\title{
MENINGKATKAN KEMAMPUAN SENI SUARA ANAK MELALUI KEGIATAN
} BERNYANYI

\author{
Hasna $^{1)}$, Sitti Rahmaniar Abubakar ${ }^{1)}$, Muhamad Safiuddin Saranani ${ }^{1)}$ \\ ${ }^{1}$ Jurusan PG-PAUD, Universitas Halu Oleo. Jln. H.E.A Mokodompit, Kendari 93232, Indonesia.
}

\begin{abstract}
Abstrak
Penelitian ini bertujuan untuk meningkatkan kemampuan seni suara anak melalui kegiatan bernyanyi di Kelompok B TK Negeri Labuan Belanda Kecamatan Wakorumba Utara Kabupaten Buton Utara . Subjek dalam penelitian ini adalah guru dan anak didik yang berjumlah 20 orang yang terdiri atas 9 orang anak perempuan dan 11 orang anak laki-laki dengan rentang usia 5-6 tahun. Jenis penelitian ini adalah penelitian tindakan kelas yang dilaksanakan dalam dua siklus. Berdasarkan analisis data hasil observasi aktivitas mengajar guru pada siklus I diperoleh persentase ketercapaian sebesar 60\%, aktivitas belajar anak didik diperoleh persentase ketercapaian sebesar 58,33\% sedangkan hasil belajar anak berupa Meningkatkan Kemampuan Seni Suara Anak Melalui Kegiatan Bernyanyi sebelum dilakukan tindakan sebesar $45 \%$ anak memperoleh nilai BSH dan MB kemudian meningkat pada siklus I sebesar $70 \%$. Pada siklus II, persentase ketercapaian aktivitas mengajar guru mengalami peningkatan menjadi 86,66\%, persentase ketercapaian aktivitas belajar anak didik juga mengalami peningkatan menjadi $91,66 \%$ dan hasil belajar anak berupa meningkatkan kemampuan seni suara anak melalui kegiatan bernyanyi meningkat sebesar $90 \%$.
\end{abstract}

Kata kunci: Seni, Anak, Bernyanyi

\section{IMPROVING THE CHILDREN VOICE ART ABILITY THROUGH SINGING ACTIVITIES}

\begin{abstract}
This study aims to improve the voice art of the children through singing activities in Group B TK Negeri Labuan Belanda North Wakorumba District Buton North Regency.The subject in this study is the teacher and children which amounted of 20 people comprising 9 girls and 11 boys by range age 5-6 years. This type of research is a classroom action research (PTK) which conducted in two cycles. Based on the results of observation data analysis of teacher teaching activity in cycle I retrieved percentage of $60 \%$, the learning activities students obtained the percentage of 53,33\% whereas child study the results of improving the children voice art ability through singing activities beforeto the action by $45 \%$ children scored BSH and MB then improved in the cycle I of 70\%. In the cycle II, the percentage of teachers teaching activity have elevated into a $86,66 \%$, the percentage of learning activities students also increased being $91,66 \%$ and child study results in the form of increased the Voice art of the Children through Singing Activities by increased $90 \%$.
\end{abstract}

Keywords: Art, Child, Singing Activity.

\section{PENDAHULUAN}

Undang-undang Republik Indonesia Nomor 20 Tahun 2003 tentang Sistem Pendidika n Nasioanl pasal 1 ayat 14, dalam Depdiknas (2008: 3) disebutkan bahwa pendidikan anak usia dini adalah suatu upaya pembinaan yang ditunjukan kepada anak sejak lahir sampai usia eman tahun, yang dilakukan dengan pemberian rangsangan pendidikan untuk membantu pertumbuhan dan perkembangan jasmani dan rohani, agar anak memiliki kesiapan dalam memasuki pendidikan lebih lanjut.

Pendidikan anak usia dini merupakan pendidikan yang paling mendasar dan menempati kedudukan sebagai golden age dan sangat strategis dalam pengembangan sumber daya manusia. Golden Age atau usia emas adalah usia 0-6 tahun yang merupakan masa depannya. Masa-masa pada rentang usia dini 
merupakan masa emas dimana perkembangan fisik, motorik, intelektual, emosional, bahasa, dan sosial berlangsung dengan sangat cepat (Direktorat PAUD, 2004: 10).

Gardner dalam Rachmi (2008: 1.6) menyatakan bahwa setiap individu mempunyai 7 jenjang kecerdasan yakni kecerdasan linguistik, kecerdasan logika matematika, kecerdasan spasial, kecerdasan kinestetik, kecerdasan interpersonal dan intrapersonal dan kecerdasan musik termaksud seni suara. Potensi kecerdasan masing-masing individu berbeda-beda, sehingga dalam memberikan pendidikan pada anak siapa pun tidak boleh memaksakan kehendak. Namun harus memahami masing-masing individu tersebut dimana dan apa potensi yang dimilikinya serta bagaimana mengelolah potensi tersebut secara tepat sehingga berguna bagi kemajuan dan kehidupan anak selanjutnya.

Leo Tolstoy dalam Pekerti (2008: 1.7) mendefinisikan bahwa seni merupakan kegiatan sadar manusia dengan perantaraan tanda-tanda lahiriah tertentu untuk menyampaikan perasaanperasaan yang telah dihayatinya kepada orang lain, sehingga mereka kejangkitan perasaan yang sama dan juga mengalaminya.

Listiana, dkk (2010:40) mendefinisikan bahwa bagaimana suara dinotasikan atau dituliskan dan bagaimana suara tersebut ditangkap dalam benak pendengarnya, dalam musik, gelombang suara biasanya dibahas tidak dalam panjang gelombangnnya maupun periodenya, melainkan dalam frekuensinya. Aspek-aspek dasar suara dalam musik biasanya di jelaskan dalam tata yaitu tinggi nada, durasi, intensitas dan timbre atau warna bunyi. Suara dapat dibagi-bagi ke dalam nada yang memiliki tinggi nada, atau tala tertentu menurut frekuensinya ataupun menurut jarak relative tinggi nada tersebut terhadap tinggi nada patokan.

Ahmadiyah (2017: 249) menyatakan

bahwa suara yang diterima oleh indera pendengaran manusia ditangkap dalam bentuk frekuensi. Dengan menggunakan frekuensi sebagai parameter fisik sebuah suara. Manusia dapat membedakan nada tinggi, nada rendah sebuah nada berbanding lurus dengan frekuensi suara.

Pekerti (2008: 3.19) mengemukahkan bahwa karakter suara anak dalam bernyanyi dapat ditinjau dari warna suara anak, batas jangkauan nada yang dapat dijangkau anak, interval yang dapat dijangkau, koordinasi dalam bernyanyi, bernapas pada taraf penyesuaian dan melakukan gerak anggota tubuh lainnya.

Berdasarkan hasil observasi awal yang dilakukan peneliti di kelompok B Taman Kanak-Kanak Negeri Labuan Belanda Kecamatan Wakorumba Utara Kabupaten Buton Utara dalam meningkatkan seni suara anak. Menunjukan pembelajaran seni suara disekolah masih rendah diminat oleh anak. Disisi lain juga peneliti mendapat kenyataan bahwa apresiasi anak terhadap seni suara masih rendah. Ternyata anak lebih fasih menyanyikan dan mengetahui secara detail lagu-lagu pop, indonesia maupun mancanegara.

Bertitik tolak pada permasalahan tersebut,maka untuk mengatasi berbagai macam permasalahan tersebut salah satunya adalah dengan penerapan kegiatan bernyanyi. Melalui kegiatan bernyanyi dapat meningkatkan kemampuan seni suara anak. dimana seni suara merupakan salah satu cabang seni musik dengan menggunakan vokal sebagai media utama untuk berekspresi atau menciptakan keindahan. Sedangkan bernyanyi adalah bentuk musik yang paling disukai dan disenangi anak, melalui kegiatan bernyanyi anak dapat mengembangkan rasa estetis dan rasa musikalnya yang ada pada dirinya.

Ma'rifah (2009: 25) bernyanyi merupakan salah satu kegiatan yang disukai anak. Dengan bernyanyi menirukan suara guru di depan bersama teman-temannya, anak akan semakin senang terhadap apa yang di pelajarinya, terutama di lingkungan sekolah. Bernyanyi dapat menjadi sarana hiburan dan juga sarana pembelajaran bagi semua usia baik untuk anak. Kita dapat memilih lagu-lagu yang pas untuk materi pembelajaran yang kita ajarkan, apabila sesuai disamping menghibur dan dapat pula menghilangkan kejenuhan. Bernyanyi juga dapat menguatkan pemahaman anak terhadap materi yang diajarkan.

Pekerti dkk (2008: 2.52) menyatakan bahwa bernyanyi merupakan suatu bagian yang penting dalam mengembangkan diri anak. Dalam bernyanyi anak-anak akan dapat mengespresikan apa yang dirasakan, dipikirkan, diimpikan secara pribadi, dan melalui nyanyianlah anak akan bersentuhan dengan sesuatu yang indah.

Miller dalam Pekerti (2008: 2.36) mengatakan bahwa bernyanyi merupakan istilah lain dari musik vokal. Bernyanyi merupakan medium musik yang pertama yang dimiliki manusia di masa lalu, suara manusia 
diperkirakan merupakan medium musikal yang mendasari medium-medium lainnya. Vokal berasal dari tubuh penyanyinya sendiri, bernyanyi merupakan gabungan dari kata-kata dan musik.

Musbikin dalam Prastyo $(2010 ; 22)$ menyatakan bahwa dalam kegiatan bernyanyi memiliki kelebihan yaitu dapat merangsang imajinasi anak, dapat memicu kreatifitas, dan memberi stimulus yang cukup kuat terhadap otak sehingga mendorong proses berfikir anak dengan cepat

\section{METODE}

Jenis penelitian yang digunakan dalam penelitian ini adalah Penelitian Tindakan Kelas (PTK). Arikunto (2010: 135) menyatakan bahwa penelitian tindakan kelas (classroom action research) adalah penelitian yang dilakukan oleh guru ke kelas atau di sekolah tempat ia mengajar dengan penekanan pada penyempurnaan atau peningkatan proses dan praksis pembelajaran.

Penelitian ini dilaksanakan di kelompok B TK Negeri Labuan Belanda Kecamatan Wakorumba Utara Kabupaten Buton Utara.

Penelitian ini dilaksanakan pada tanggal 7 Maret 2018 yaitu semester ganjil tahun ajaran 2017/2018.

Subjek dalam penelitian ini adalah guru dan anak didik yang berjumlah 20 orang yang terdiri atas 9 orang anak perempuan dan 11 orang anak laki-laki dengan rentang usia 5-6 tahun.

Adapun faktor-faktor yang diteliti dan diamati dalam penelitian ini adalah sebagai berikut:

1. Faktor guru, aktivitas mengajar guru.

2. Faktor anak, aktivitas belajar dan hasil belajar anak dalam mengikuti kegiatan pembelajaran.

3. Hasil belajar anak.

Pengumpulan data dalam penelitian ini dihimpun melalui hasil observasi, dokumentasi dan wawancara. Observasi adalah suatu teknik yang dapat dilakukan guru untuk mendapatkan berbagai informasi atau data tentang peremabangan dan permasalahan anak. Melalui pengamatan, guru dapat mengetahui perkembangan yang terjadi pada anak dalam kurun waktu tertentu. Observasi dilakukan oleh guru Kelompok B sebagai observer dengan menggunakan lembar observasi. Penggunaan lembar observasi ini untuk melihat proses pelaksanaan pembelajaran yang dilaksanakan oleh guru ketika melakukan kegiatan pengelompokkan benda untuk meningkatkan kemampuan kognitif anak. Dokumentasi yaitu mencari data mengenai hal-hal atau variable yang berupa catatan, transkrip, buku, surat kabar, majalah, prasasti, notulen rapat, lengger, agenda dan sebagainya (Arikunto, 2010: 274). Dokumentasi ini berupa foto guru/peneliti pada saat proses meneliti sebagai bukti dalam melakukan kegiatan penelitian di lapangan. Wawancara adalah suatu tehnik pengumpulan data yang dapat dilakukan guru untuk mendapatkan informasi tentang perkembangan dan permasalahan anak dengan cara melakukan percakapan langsung, baik dengan anak maupun orang tua.

Analisis data merupakan cara yang dilakukan untuk mengetahui keefektifan suatu metode dalam kegiatan pembelajaran (Aqib, 2009:203)

Pengelolaan data dalam penelitian ini disesuaikan dengan teknik penilaian di TK yaitu dengan menggunakan tanda sebagai berikut: Belum Berkembang $(\mathrm{BB})=*$, Mulai Berkembang $(\mathrm{MB})=* *$, Berkembang Sesuai Harapan $=* * *$, Berkembang Sangat Baik $=* * * *$ (Depdiknas, 2004: 26).

Tabel 1. Kategori Keberhasilan Klasikal

\begin{tabular}{ccc}
\hline Persentase & Kategori & Simbol \\
\hline $95 \%-100 \%$ & (BSB) & $* * *$ \\
\hline $85 \%-94 \%$ & $(\mathrm{BSH})$ & $* * *$ \\
\hline $75 \%-84 \%$ & $(\mathrm{MB})$ & $* *$ \\
\hline$<75 \%$ & $(\mathrm{BB})$ & $*$ \\
\hline
\end{tabular}

Indikator keberhasilan dalam penelitian ini terdiri dari indikator proses dan indikator hasil (nilai). Apabila rencana kegiatan pembelajran terlaksana minimal $85 \%$ baik secara individu maupun klasikal di kelompok B di TK Negeri Labuan Belanda Kecamatan Wakorumba Utara Kabupaten Buton Utara, dengan pencapaian nilai Berkembang Sesuai Harapan (BSH) dan berkembang sangat baik (BSB) maka pelaksanaannya dikatakan berhasil.

\section{HASIL DAN PEMBAHASAN}

Sebelum kegiatan penelitian ini dilaksanakan, peneliti terlebih dahulu melakukan pertemuan awal dengan kepala TK Negeri Labuan Belanda Kecamatan Wakorumba Utara Kabupaten Buton Utara yaitu pada tanggal 3 februari 2018, pertemuan ini bermaksud untuk menyampaikan tujuan dari peneliti yaitu mengadakan penelitian di TK Negeri Labuan 
Belanda Kecamatan Wakorumba Utara Kabupaten Buton Utara . Selanjutnya, kepala TK mengarahkan peneliti untuk berdiskusi dengan guru Kelompok B.

Setelah itu, peneliti melakukan observasi awal di Taman Kanak-kanak Negeri Labuan Belanda Kecamatan Wakorumba Utara Kabupaten Buton Utara khususnya pada Kelompok B pada tanggal 2 maret 2018. Berdasarkan hasil observasi dan dilanjutkan dengan wawancara singkat dengan guru kelompok B di taman kanak-kanak tersebut, bahwa dalam kegiatan pembelajaran berbagai pendekatan, model, dan metode digunakan dan diterapkan pada proses pembelajaran anak usia dini namun kenyataannya di lapangan masih ditemukan bahwa dalam meningkatkan kemampuan seni suara anak melalui kegiatan bernyanyi belum sepenuhnya dilakukan.

Berdasarkan permasalahan yang dihadapi tersebut, maka peneliti merancang suatu bentuk kegiatan pembelajaran yang menarik dan menyenangkan bagi anak mengenai meningkatkan kemampuan seni suara anak melalui kegiatan bernyanyi. Selanjutnya, peneliti bersama guru Kelompok B TK Negeri Labuan Belanda Kecamatan Wakorumba Utara Kabupaten Buton Utara, sepakat untuk berkolaborasi dalam kegiatan penelitian ini.

Penelitian ini dilakukan dengan tindakan siklus 1 yang masing-masing siklus terdiri dari empat kali pertemuan dan mengikuti empat tahapan kegiatan yaitu perencanaan,pelaksanaan tindakan,observasi dan evaluasi, dan refleksi. Hal-hal yang dilakukan dalam tahap ini adalah menyiapkan RKH dan RKM,media yang digunakan, lembar observasi anak dan guru serta alat evaluasi/penilaian.

Pelaksanaan tindakan siklus I pertemuan I dilaksanakan pada hari rabu, 7 maret 2018 pada pukul 07.30-11.00 WITA dengan menggunakan tema kendaraan dan sub tema kendaraan di darat dengan tema spesifik yaitu kendaraan di darat (sepeda).Adapun indikator yang harus dicapai anak didik pada setiap pertemuan yaitu anak dapat menirukan lagu yang dinyanyikan oleh guru, Anak dapat meniru berekspresi dengan benar sesuai irama lagu yang didengarkan, Anak dapat menyanyikan lagu dengan benar, Anak dapat menyanyikan lagu sambil berekspresi dengan benar sesuai irama lagu.

Pada pelaksanaan tindakan ini, penelitian melaksanakan skenario pembelajaran pada RPPH Siklus II, yaitu sebelum kegiatan pembelajaran dimulai, guru telah menyiapkan media pembelajaran yang akan diberikan kepada anak, kemudian aktivitas sebelum kegiatan pembelajaran dimulai, didahului dengan apel /berbaris yang dipimpin oleh guru. Pada saat berbaris, barisan anak dirapikan, anak didik menyanyikan lagu yang sering mereka nyanyikan tiap apel pagi, kemudian anak masuk kelas sambil mengucapkan salam.

Pada kegiatan inti guru bercerita tentang tema yang akan dibawakan yaitu tema kendaraan sub tema kendaraan di darat tema spesifik (sepeda), setelah guru menjelaskan maksud dari kegiatan yang akan dilakukan sesuai tema pada hari ini. Guru telah menyiapkan media berupa gambar sepeda dan menyanyikan lagu ada sepeda kemudian memi nta anak untuk menyebutkan bentuk sepeda dan menyanyikan lagu "ada sepeda

Kegiatan akhir, guru memberikan nasehat-nasehat dan tanya jawab serta kesimpulan tentang kegiatan yang telah dilakukan pada hari ini, selanjutnya manyanyikan beberapa lagu dan berdoa sebelum pulang.

Pelaksanaan tindakan siklus I pertemuan II dilaksanakan pada hari kamis, 8 maret 2018 pada pukul 07.30-11.00 WITA. Adapun indikator yang harus dicapai anak didik adalah sama dengan indikator sebelumnya yaitu anak dapat menirukan lagu yang dinyanyikan oleh guru, Anak dapat meniru berekspresi dengan benar sesuai irama lagu yang didengarkan, Anak dapat menyanyikan lagu dengan benar, Anak dapat menyanyikan lagu sambil berekspresi dengan benar sesuai irama lagu. sebelum kegiatan pembelajaran dimulai, guru telah menyiapkan media pembelajaran yang akan diberikan kepada anak, kemudian aktivitas sebelum kegiatan pembelajaran dimulai, didahului dengan apel /berbaris yang dipimpin oleh guru. Pada saat berbaris, barisan anak dirapikan, anak didik menyanyikan lagu yang sering mereka nyanyikan tiap apel pagi, kemudian anak masuk kelas sambil mengucapakan salam.

Pada kegiatan inti guru bercerita tentang tema yang akan dibawakan yaitu tema kendaraan sub tema kendaraan di darat tema spesifik (becak), setelah guru menjelaskan maksud dari kegiatan yang akan dilakukan sesuai tema pada hari ini. Guru telah menyiapkan media berupa gambar becak kemudian meminta anak untuk menyebutkan bentuk, warna becak. Anak dengan satu persatu 
menyebutkan bentuk, warna becak dan menyanyikan lagu "becak" dalam Umar (2011: 14). selanjutnya dalam kegiatan bernyanyi lagu becak masih membutuhkan bantuan guru, dan ada beberapa anak yang sudah bisa menyanyikan dengan benar.

Kegiatan akhir, guru memberikan nasehat-nasehat dan tanya jawab serta kesimpulan tentang kegiatan yang telah dilakukan pada hari ini, selanjutnya manyanyikan beberapa lagu dan berdoa sebelum pulang.

Pelaksanaan tindakan siklus I pertemuan III dilaksanakan pada hari jumat, 9 maret 2018 pada pukul 07.30-11.00 WITA. dengan menggunakan tema kendaraan dan sub tema kendaraan di darat dengan tema spesifik yaitu kendaraan di darat (mobil). . Adapun indikator yang harus dicapai yaitu anak dapat menirukan lagu yang dinyanyikan oleh guru, Anak dapat meniru berekspresi dengan benar sesuai irama lagu yang didengarkan, Anak dapat menyanyikan lagu dengan benar, Anak dapat menyanyikan lagu sambil berekspresi dengan benar sesuai irama lagu.

Pada pelaksanaan tindakan ini, penelitian melaksanakan scenario pembelajaran pada RPPH Siklus I, yaitu sebelum kegiatan pembelajaran dimulai, guru telah menyiapkan media pembelajaran yang akan diberikan kepada anak, kemudian aktivitas sebelum kegiatan pembelajaran dimulai, didahului dengan apel /berbaris yang dipimpin oleh guru. Pada saat berbaris, barisan anak dirapikan, anak didik menyanyikan lagu yang sering mereka nyanyikan tiap apel pagi, kemudian anak masuk kelas sambil mengucapakan salam .

Pada kegiatan inti guru bercerita tentang tema yang akan dibawakan yaitu tema kendaraan sub tema kendaraan di darat tema spesifik (mobil), setelah guru menjelaskan maksud dari kegiatan yang akan dilakukan sesuai tema pada hari ini. Guru telah menyiapkan media gambar mobil, kemudian meminta anak untuk menyebutkan warna dan bentuk mobil dan menyanyikan lagu tepuk mobil. selanjutnya guru menyuruh anak untuk menyanyikan lagu tepuk mobil, Pada kegiatan menyanyikan lagu tepuk mobil masih membutuhkan bantuan guru, dan ada beberapa anak yang sudah bisa menyanyikan lagu tepuk mobil.

Kegiatan akhir, guru memberikan nasehat-nasehat dan tanya jawab serta kesimpulan tentang kegiatan yang telah dilakukan pada hari ini, selanjutnya manyanyikan beberapa lagu dan berdoa sebelum pulang.

Pelaksanaan tindakan siklus I pertemuan IV dilaksanakan pada hari sabtu, 10 maret 2018 pada pukul 07.30-11.00 WITA. dengan menggunakan tema kendaraan dan sub tema kendaraan di darat dengan tema spesifik yaitu kendaraan di darat (kereta). Adapun indikator yang harus dicapai anak yaitu anak dapat menirukan lagu yang dinyanyikan oleh guru, Anak dapat meniru berekspresi dengan benar sesuai irama lagu yang didengarkan, Anak dapat menyanyikan lagu dengan benar, Anak dapat menyanyikan lagu sambil berekspresi dengan benar sesuai irama lagu.

Pada pelaksanaan tindakan ini, penelitian melaksanakan scenario pembelajaran pada RPPH Siklus I, yaitu sebelum kegiatan pembelajaran dimulai, guru telah menyiapkan media pembelajaran yang akan diberikan kepada anak, kemudian aktivitas sebelum kegiatan pembelajaran dimulai, didahului dengan apel /berbaris yang dipimpin oleh guru. Pada saat berbaris, barisan anak dirapikan, anak didik menyanyikan lagu yang sering mereka nyanyikan tiap apel pagi, kemudian anak masuk kelas sambil mengucapakan salam.

Pada kegiatan inti guru bercerita tentang tema yang akan dibawakan yaitu tema kendaraan sub tema kendaraan di darat tema spesifik (kereta), setelah guru menjelaskan maksud dari kegiatan yang akan dilakukan sesuai tema pada hari ini. Guru telah menyiapkan media berupa gambar kereta kemudian meminta anak untuk menyebutkan bentuk, warna kereta. Anak dengan satu persatu menyebutkan bentuk, warna kereta dan menyanyikan lagu naik kereta. Selanjutnya dalam kegiatan bernyanyi lagu naik kereta masih membutuhkan bantuan guru, dan ada beberapa anak yang sudah bisa menyanyikan dengan benar.

Kegiatan akhir, guru memberikan nasehat-nasehat dan tanya jawab serta kesimpulan tentang kegiatan yang telah dilakukan pada hari ini, selanjutnya manyanyikan beberapa lagu dan berdoa sebelum pulang.

Selama proses pembelajaran berlangsung, guru sebagai observer mengamati jalannya pembelajaran dengan menggunakan lembar observasi untuk guru dan lembar observasi untuk anak. Kegiatan observasi dilakukan 
bersamaan dengan pelaksanaan tindakan untuk setiap pertemuan pada siklus I.

Hasil analisis pengamatan guru sesuai dengan lembar observasi sebanyak 15 aspek yang diamati harus dicapai guru. Pada siklus I skor yang dicapai oleh guru dari 15 aspek hanya 9 aspek dengan persentase ( $60 \%$ ) di antaranya (a) guru mempersiapkan anak untuk belajar. (b) guru mengucapkan salam. (c) guru membimbing anak untuk berdoa sebelum belajar. (d) guru mempersiapkan media pembelajaran. (e) guru memperlihatkan kepada anak macam-macam gambar kendaraan. (f) guru mengajak anak untuk menyanyikan lagu. (g) guru mengajak anak untuk bersama-sama berekspresi sambil bernyanyi sesuai irama lagu. (h) guru memberikan kesimpulan terhadap kegiatan yang akan dilakukan (i) guru membimbing anak untuk berdoa sebelum pulang.

Sedangkan yang tidak tercapai sebanyak 6 aspek dengan persentase ( $40 \%$ ) diantaranya (a) guru melakukan apresiasi dengan tema kendaraan. (b) guru menjelaskan tujuan pembelajaran yang akan dilaksanakan yang berkaitan dengan tema kendaraan. (c) guru mencotohkan kepada anak berekspresi sesuai irama lagu. (d) guru mempersilahkan kepada anak untuk berekspresi sambil bernyanyi sesuai irama lagu. (e) guru melakukan Tanya jawab tentang kegiatan hari ini. (f) guru memberikan penguatan, motivasi kepada anak. Untuk lebih jelasnya dapat dilihat pada histogram berikut:

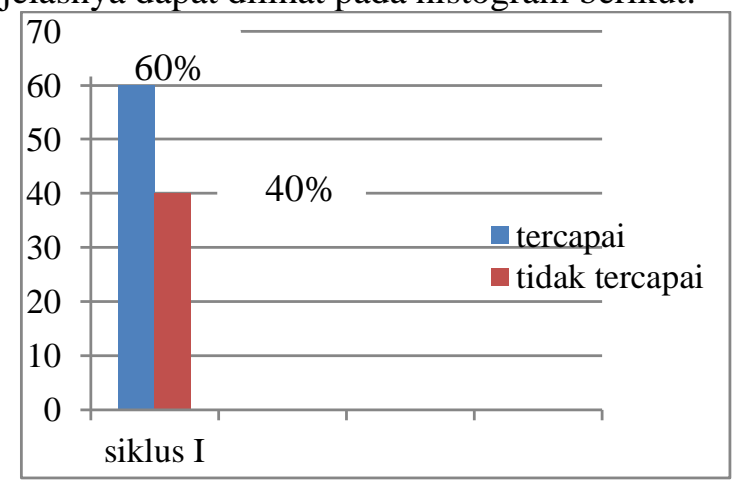

Gambar. 1. Histogram Hasil Analisis Aktivitas Mengajar Guru Siklus I

Analisis hasil observasi anak sesuai dengan lembar observasi pada siklus I sebanyak 12 aspek yang diamati diharapkan tercapai, namun yang tercapai hanya sebanyak 7 aspek 58,33\% diantaranya (a) anak mengucapkan salam. (b) anak mendengarkan apresiasi sebelum pembelajaran. (c) anak mengetahui macam- macam gambar kendaraan. (d) anak mengikuti guru menyanyikan lagu. (e) anak mendengarkan nasehat, motivasi dan penguatan. (f) anak mendengarkan kesimpulan tentang kegiatan pembelajaran pada hari ini. (g) anak bersama guru berdoa dan memberi salam sebelum pulang.

Sedangkan yang tidak tercapai sebanyak 5 aspek 41,67\% diantaranya (a) anak memperlihatkan sikap tenang. (b) anak mengikuti guru berekspresi sambil bernyanyi sesuai irama lagu. (c) anak bersama-sama berekspresi sambil bernyanyi sesuai irama lagu. (d) anak bergerak sambil bernyanyi sesuai irama musik.. (e) anak mengadakan Tanya jawab dengan guru tentang kegiatan pada hari ini. Data tersebut dapat digambarkan dalam histogram berikut:

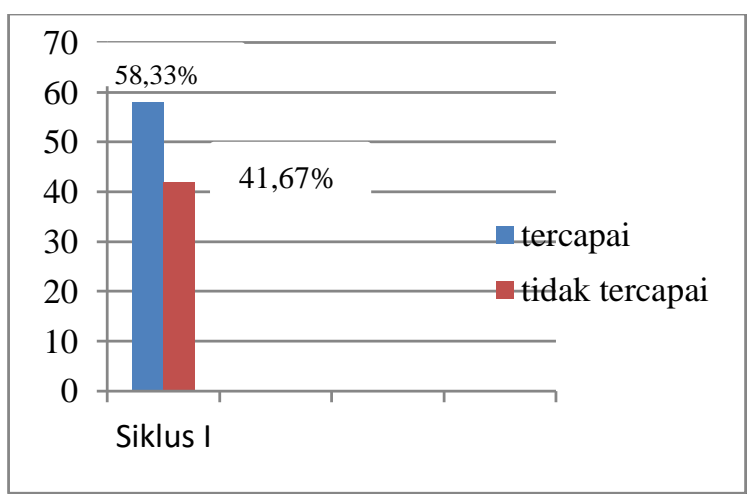

Gambar 2. Histogram Hasil Analisis Belajar Anak Siklus I

Berdasarkan data yang diperoleh dari hasil evaluasi pada siklus I dapat diketahui bahwa dalam meningkatkan kemampuan seni suara anak melalui kegiatan bernyanyi di kelompok B TK Negeri Labuan Belanda Kecamatan Wakorumba Utara Kabupaten Buton Utara pada siklus I, secara klasikal pada siklus I mencapai tingkat keberhasilan sekitar 70\% dengan 20 anak, dimana rata-rata anak memperoleh nilai bintang $(* * *)$ atau Berkembang sesuai Harapan dengan peresentase $50 \%$ yaitu 10 orang anak didik dari 20 orang anak keseluruhan. nilai bintang $(* * * *)$ atau Berkembang Sangat Baik dengan persentase $20 \%$ yaitu diperoleh 4 orang anak didik. Untuk nilai bintang $(* *)$ atau Mulai Berkembang dengan $25 \%$ yaitu diperoleh 5 orang anak didik dan nilai bintang (*) dengan persentase 5\% yaitu diperoleh 1 orang anak didik.

Berdasarkan hasil evaluasi tersebut, sebagian besar anak didik sudah dapat melaksanakan kegiatan bernyanyi dengan baik. 
Hal ini tentu saja akan dihubungkan dengan indicator kinerja yang ditetapkan yaitu jika anak didik mencapai tingkat perolehan nilai keberhasilan sebesar $85 \%$. Tindakan siklus I hanya mencapai perolehan nilai sebesar $70 \%$, maka dapat dikatakan bahwa penelitian tindakan ini belum terselesaikan dan hal ini akan dilanjutkan pada tahapan siklus selajutnya yaitu siklus II.

Dari hasil observasi, maka beberapa hal yang harus diperbaiki adalah Kurangnya kemampuan peneliti dalam mengelola kelas, Peneliti kurang aktif dalam melakukan tanya jawab dengan anak,Peneliti masih kurang dalam memyampaikan tujuan pembelajaran yang dilakukan.

Pelaksanaan tindakan siklus II pertemuan I dilaksanakan pada hari Senin, 12 maret 2018 pada pukul 07.30-11.00 WITA. dengan menggunakan tema kendaraan dan sub tema kendaraan di udara dengan tema spesifik yaitu kendaraan di uadar (balon udara). Adapun indikator yang harus dicapai anak didik pada setiap pertemuan adalah anak dapat menirukan lagu yang dinyanyikan oleh guru, Anak dapat meniru berekspresi dengan benar sesuai irama lagu yang didengarkan, Anak dapat menyanyikan lagu dengan benar, Anak dapat menyanyikan lagu sambil berekspresi dengan benar sesuai irama lagu.

Pada pelaksanaan tindakan ini, penelitian melaksanakan skenario pembelajaran pada RPPH Siklus II, yaitu sebelum kegiatan pembelajaran dimulai, guru telah menyiapkan media pembelajaran yang akan diberikan kepada anak, kemudian aktivitas sebelum kegiatan pembelajaran dimulai, didahului dengan apel /berbaris yang dipimpin oleh guru. Pada saat berbaris, barisan anak dirapikan, anak didik menyanyikan lagu yang sering mereka nyanyikan tiap apel pagi, kemudian anak masuk kelas sambil mengucapkan salam.

Pada kegiatan inti guru bercerita tentang tema yang akan dibawakan yaitu tema kendaraan sub tema kendaraan di udara tema spesifik (balon udara), setelah guru menjelaskan maksud dari kegiatan yang akan dilakukan sesuai tema pada hari ini. Guru telah menyiapkan media berupa gambar balon udara dan menyanyikan lagu kemudian meminta anak untuk menyebutkan bentuk, warna balon udara serta menyanyikan lagu balon udara. Anak dalam menyanyikan lagu masih membutuhkan bantuan guru, dan ada beberapa anak yang sudah bisa menyanyikan lagu balon.

Kegiatan akhir, guru memberikan nasehat-nasehat dan tanya jawab serta kesimpulan tentang kegiatan yang telah dilakukan pada hari ini, selanjutnya manyanyikan beberapa lagu dan berdoa sebelum pulang.

Pelaksanaan tindakan siklus II pertemuan II dilaksanakan pada hari selasa, 13 maret 2018 pada pukul 07.30-11.00 WITA. dengan menggunakan tema kendaraan dan sub tema kendaraan di uadara dengan tema spesifik yaitu kendaraan di udara (pesawat). Adapun indikator yang harus dicapai anak didik adalah sama dengan indikator sebelumnya yaitu anak dapat menirukan lagu yang dinyanyikan oleh guru, Anak dapat meniru berekspresi dengan benar sesuai irama lagu yang didengarkan, Anak dapat menyanyikan lagu dengan benar, Anak dapat menyanyikan lagu sambil berekspresi dengan benar sesuai irama lagu.

Pada pelaksanaan tindakan ini, penelitian melaksanakan skenario pembelajaran pada RPPH Siklus II, yaitu sebelum kegiatan pembelajaran dimulai, guru telah menyiapkan media pembelajaran yang akan diberikan kepada anak, kemudian aktivitas sebelum kegiatan pembelajaran dimulai, didahului dengan apel /berbaris yang dipimpin oleh guru. Pada saat berbaris, barisan anak dirapikan, anak didik menyanyikan lagu yang sering mereka nyanyikan tiap apel pagi, kemudian anak masuk kelas sambil mengucapkan salam.

Pada kegiatan inti guru bercerita tentang tema yang akan dibawakan yaitu tema kendaraan sub tema kendaraan di udara tema spesifik (pesawat), setelah guru menjelaskan maksud dari kegiatan yang akan dilakukan sesuai tema pada hari ini. Guru meminta anak menyanyikan lagu pesawat, Selanjutnya itu anak dalam kegiatan menyanyikan lagu pesawat, ketika kegiatan menyanyikan lagu masih bantu guru, dan ada beberapa anak yang sudah bisa bernyanyi dengan benar.

Kegiatan akhir, guru memberikan nasehat-nasehat dan tanya jawab serta kesimpulan tentang kegiatanp yang telah dilakukan pada hari ini, selanjutnya manyanyikan beberapa lagu dan berdoa sebelum pulang.

Pelaksanaan tindakan siklus II pertemuan III dilaksanakan pada hari rabu, 14 maret 2018 pada pukul 07.30-11.00 WITA. dengan menggunakan tema kendaraan dan sub tema 
kendaraan di udara dengan tema spesifik yaitu kendaraan di udara (helikopter). . Adapun indikator yang harus dicapai anak yaitu anak dapat menirukan lagu yang dinyanyikan oleh guru, Anak dapat meniru berekspresi dengan benar sesuai irama lagu yang didengarkan, Anak dapat menyanyikan lagu dengan benar, Anak dapat menyanyikan lagu sambil berekspresi dengan benar sesuai irama lagu

Pada pelaksanaan tindakan ini, penelitian melaksanakan skenario pembelajaran pada RPPH Siklus II, yaitu sebelum kegiatan pembelajaran dimulai, guru telah menyiapkan media pembelajaran yang akan diberikan kepada anak, kemudian aktivitas sebelum kegiatan pembelajaran dimulai, didahului dengan apel /berbaris yang dipimpin oleh guru. Pada saat berbaris, barisan anak dirapikan, anak didik menyanyikan lagu yang sering mereka nyanyikan tiap apel pagi, kemudian anak masuk kelas sambil mengucapkan salam.

Pada kegiatan inti guru bercerita tentang tema yang akan dibawakan yaitu tema kendaraan sub tema kendaraan di udara tema spesifik (helikopter), setelah guru menjelaskan maksud dari kegiatan yang akan dilakukan sesuai tema pada hari ini. Guru telah menyiapkan media gambar helikopter, kemudian meminta anak untuk menyebutkan warna dan bentuk helikopter, dan menyuru anak untuk menyanyikan lagu helikopter. Pada kegiatan menyanyikan lagu helikopter masih membutuhkan bantuan guru, dan ada beberapa anak yang sudah bisa menyanyikan lagu helikopter.

Kegiatan akhir, guru memberikan nasehat-nasehat dan tanya jawab serta kesimpulan tentang kegiatan yang telah dilakukan pada hari ini, selanjutnya manyanyikan beberapa lagu dan berdoa sebelum pulang.

Pelaksanaan tindakan siklus II pertemuan IV dilaksanakan pada hari kamis, 15 maret 2018 pada pukul 07.30-11.00 WITA. dengan menggunakan tema kendaraan dan sub tema kendaraan di udara dengan tema spesifik yaitu kendaraan di uadar (balon udara). Adapun indikator yang harus dicapai anak didik pada setiap pertemuan yaitu anak dapat menirukan lagu yang dinyanyikan oleh guru, Anak dapat meniru berekspresi dengan benar sesuai irama lagu yang didengarkan, Anak dapat menyanyikan lagu dengan benar, Anak dapat menyanyikan lagu sambil berekspresi dengan benar sesuai irama lagu.

Pada kegiatan inti guru bercerita tentang tema yang akan dibawakan yaitu tema kendaraan sub tema kendaraan di udara tema spesifik (balon udara), setelah guru menjelaskan maksud dari kegiatan yang akan dilakukan sesuai tema pada hari ini. Guru telah menyiapkan media berupa gambar balon udara dan menyanyikan lagu kemudian meminta anak untuk menyebutkan bentuk serta warna apa saja yang terrdapat pada balon udara. Anak dalam menyanyikan lagu masih membutuhkan bantuan guru, dan ada beberapa anak yang sudah bisa menyanyikan lagu balon.

Kegiatan akhir, guru memberikan nasehat-nasehat dan tanya jawab serta kesimpulan tentang kegiatan yang telah dilakukan pada hari ini, selanjutnya manyanyikan beberapa lagu dan berdoa sebelum pulang.

Selama proses pembelajaran berlangsung, guru sebagai observer mengamati jalannya pembelajaran dengan menggunakn lembar observasi untuk guru dan lembar observasi untuk anak. Kegiatan observasi dilakukan bersamaan dengan pelaksanaan tindakan untuk setiap pertemuan pada siklus II.

Hasil analisis pengamatan guru sesuai dengan lembar observasi sebanyak 15 aspek yang diamati harus dicapai guru. Pada siklus II skor yang dicapai oleh guru dari 15 aspek hanya 13 aspek $(86,66 \%$ ) di antaranya (a) guru mempersiapkan anak untuk belajar. (b) guru mengucapkan salam. (c) guru membimbing anak untuk berdoa sebelum belajar. (d) guru mempersiapkan media pembelajaran. (e) guru menjelaskan tujuan pembelajaran yang akan dilaksakan yang berkaitan dengan tema kendaraan (f) guru memperlihatkan kepada anak macam-macam gambar kendaraan. (g) guru mengajak anak untuk menyanyikan lagu. (h) guru mengajak anak untuk bersama-sama berekspresi sambil bernyanyi sesuai irama lagu (i) guru mengajak anak untuk bersama-sama berekspres sambil bernyanyi sesuai irama lagu (j) guru mempersilahkan kepada anak untuk berekspresi sambil bernyanyi sesuai irama lagu. (k) guru melakukan Tanya jawab kepada anak tentang kegiatan yang dilakukan pada hari ini.(l)guru memberikan penguatan,nasehatk epada anak. (m) guru membimbing anak untuk berdoa sebelum pulang.

Sedangkan yang tidak tercapai sebanyak 2 aspek diantaranya (a) guru melakukan 
apresiasi dengan tema kendaraan. (b) guru memberikan kesimpulan terhadap kegiatan yang dilakukan pada hari ini. Untuk lebih jelas digambarkan pada histogram berikut:

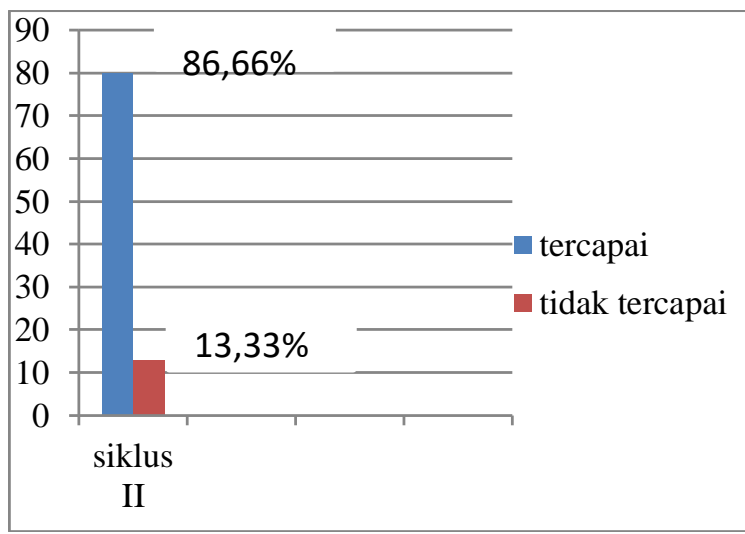

Gambar 3. Histogram Hasil Analisis Aktivitas Mengajar Guru Siklus II

Analisis hasil observasi anak dengan lembar observasi pada siklus II sebanyak 12 aspek yang diamati diharapkan tercapai, namun yang tercapai hanya sebanyak 11 aspek dengan persentase $91,66 \%$ diantaranya (a) anak mengucapkan salam (b) anak mengetahui gambar macam-macam kendaraan (c) anak mengikuti guru menyanyikan lagu (d) anak mengikuti guru berekspresi sesuai irama lagu (e) anak bersama-sama berekspresi sambil bernyanyi sesuai irama musik (f) anak berekspresi sambil bernyanyi sesuai irama lagu (g) anak mengadakan Tanya jawab dengan guru tentang kegiatan pada hari itu (h) anak mendengar nasehat,motivasi dan penguatan (i) anak mendengarkan kesimpulan tentang kegiatan pada hari ini (j) anak bersama guru berdoa dan memberi salam sebelum pulang.

Sedangkan yang tidak tercapai sebanyak 1 aspek dengan persentase $8.33 \%$ diantaranya (a) anak memperlihatkan sikap tenang. Data tersebutkan dapat digambarkan dalam histogram berikut:

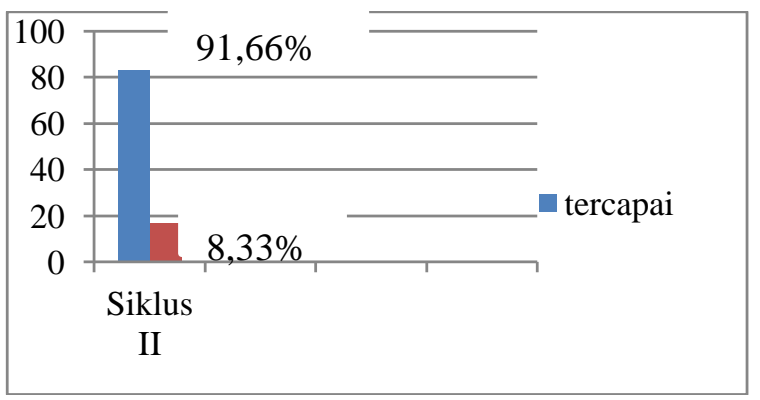

Gambar 4. Histogram Hasil Analisis Belajar Anak Siklus II.
Tabel 2. Nilai Klasikal pada siklus II

\begin{tabular}{ccc}
\hline Kategori & $\begin{array}{c}\text { Frekuensi } \\
(\mathbf{F})\end{array}$ & $\begin{array}{c}\text { Persentase } \\
(\boldsymbol{\%})\end{array}$ \\
\hline$(\mathrm{BSB})$ & 8 & $40 \%$ \\
\hline$(\mathrm{BSH})$ & 10 & $50 \%$ \\
\hline$(\mathrm{MB})$ & 2 & $10 \%$ \\
\hline$(\mathrm{BB})$ & 0 & $0 \%$ \\
\hline Jumlah & 20 & 100 \\
\hline
\end{tabular}

Berdasarkan data hasil perolehan nilai anak yang ditampilkan pada tabel 2. tersebut, maka dapat disimpulkan bahwa secara klasikal perolehan nilai anak dalam kegiatan meningkatkan kemampuan seni suara anak melalui kegiatan bernyanyi di kelompok B TK Negeri Labuan Belanda Kecamatan Wakorumba Utara Kabupaten Buton Utara mengalami peningkatan, karena tingkat keberhasilan anak yaitu sebesar 90\%. Anak yang memperoleh bintang $(* * * *)$ atau Berkembang baik (BSB) yaitu 8 orang anak didik dengan persentase $40 \%$, nilai bintang $(* * *)$ atau Berkembang Sesuai Harapan (BSH) yaitu sebanyak 10 orang anak dengan peresentase $50 \%$. Dan yang memperoleh nilai bintang (**) atau Mulai Berkembang (MB) yaitu sebanyak 2 orang anak didik dengan persentase $10 \%$. Walaupun masih terdapat anak didik yang memperoleh nilai bintang $(* *)$ atau Mulai Berkembang tetapi dapat dikatakan bahwa sebagian besar anak didik dipandang telah mampu menyelesaikan tugas-tugas yang telah ditetapkan sesuai indikator penilaian yaitu $85 \%$ dalam penelitian ini khususnya dalam pelaksanaan siklus II. Sehingga secara umum dapat dikatakan bahwa program kegiatan atau rangkaian pelaksanaan pembelajaran dalam meningkatkan kemampuan seni suara anak melalui kegiatan bernyanyi di TK Negeri Labuan Belanda Kecamatan Wakorumba Utara Kabupaten Buton Utara dipandang telah terselesaikan dan mencapai indikator kinerja yaitu $90 \%$.

Berdasarkan hasil penelitian tindakan siklus II sesuai dengan rencana yang telah ditetapkan sebelumnya. Hal ini berdasarkan hasil diskusi antara peneliti dan Observer kelompok B dimana terlihat bahwa kegiatan bernyanyi yang dilakukan anak telah berhasil, keberhasilan anak secara klasikal sudah mencapai presentase keberhasilan $90 \%$. 
Persentase tersebut sudah melebihi target indikator kinerja yaitu $85 \%$.

Berdasarkan permasalahan yang telah dirumuskan dalam penelitian ini, tujuan yang ingin dicapai oleh peneliti yaitu Untuk mengetahui Apakah dengan Melalui Kegiatan Bernyanyi dapat Meningkatkan Kemampuan Seni Suara Anak di Kelompok B TK Negeri Labuan Belanda Kecamatan Wakorumba Utara Kabupaten Buton Utara. Penelitian ini dilaksanakan dalam dua siklus, dimana setiap siklus terdiri dari empat kali pertemuan sesuai dengan prosedur penelitian yang telah dirancang sebelumnya. Setiap pertemuan terdiri dari tiga tahap yaitu kegiatan awal, kegiatan inti dan kegiatan akhir.

\section{KESIMPULAN DAN SARAN Kesimpulan}

Berdasarkan hasil penelitian yang dilakukan pada anak didik Kelompok B, dalam hal Meningkatkan Kemampuan Seni Suara Anak melalui Kegiatan Bernyanyi mengalami peningkatkan. Hal ini dapat dilihat pada hasil sesudah tindakan. Pada siklus I mencapai persentase sebesar $70 \%$ dan mengalami peningkatan pada siklus II sebesar $90 \%$. Sedangkan analisis hasil belajar anak mengalami peningkatan terlihat bahwa anak sudah mampu memahami pembelajaran yang diberikan, terlihat ketika anak sudah bisa menirukan lagu yang dinyanyikan oleh guru dan ketika anak sudah bisa menghafalkan lagu dengan benar walaupun masih sering lupa tetapi dengan adanya kegiatan bernyanyi dapat membantu anak dalam meningktakan kemampuan seni suara anak.

\section{Saran}

Setelah melaksanakan tindakan penelitian maka peneliti menyarankan hal-hal diantaranya sebaiknya guru menggunakan pembelajaran yang menarik bagi anak dalam kegiatan bernyanyi sebagai salah satu cara untuk meningkatkan kemampuan seni suara anak karena hasil penelitian bahwa melalui kegiatan bernyanyi dapat meningkatkan kemampuan seni suara anak.

\section{DAFTAR PUSTAKA}

Ahmadiyah. 2017. Sistem Rekomendasi Lagu Berdasarkan Jenis Suara Penyanyi pada Aplikasi Karauke. Jurnal Ilmiah Teknologi Informati, 15 (2).
Anonim. 2003. Undang-Undang RI No 20 Tahun 2003 Tentang Sistem Penidikan Nasional. Jakarta: Depdiknas.

Aqib, Zainal. 2009. Penelitian Tindakan Kelas. Bandung: CV. Yrama Widya.

Arikunto, Suharsimi. 2010. Prosedur Penelitian Suatu Pendekatan Praktek. Jakarta: Rineka Cipta.

Depdiknas. 2004. Pedoman Penilaian di Taman Kanak-Kanak. Jakarta: Depdiknas.

Depdiknas. 2008. Kutikuum Tingkat Satuan Pendidikan. Jakarta: Dikmenum. Depdiknas.

Direktorat Pendidikan Anak Usia Dini . 2004. Acuan Menu Pembelajaran Pada Pendidikan Anak Usia Dini. Jakarta: Depdiknas.

Listiana, dkk. 2010. Seni Budaya dan Keterampilan. Tangerang Selatan: Prima Duta Nusantara

Ma'rifah. 2009. Strategi Pembelajaran BCM (Bermain, Cerita, Bernyanyi) dalam Membina Akhlak Anak Usia Dini. Skripsi. Malang: UIN Maulana Malik Ibrahim malang

Nanang, Ganda Prawira. 2007. Seni rupa dan kriya. Bandung: Sarana Tutorial Nurani.

Pekerti, Widia dkk. 2008. Metode Pengembangan seni. Jakarta: Universitas terbuka.

Prastyo. 2010. Menyanyi Sebagai Metode Untuk Meningkatkan Penguasan Kosa Kata Bahasa Iggris. Jakarta: PT Gramedia.

Rachmi, Tetty dkk. 2008. Keterampilan Musik dan Tari. Jakarta: Universitas Terbuka. 